\title{
Zinc Finger Transcription Factor Trps1
}

National Cancer Institute

\section{Source}

National Cancer Institute. Zinc Finger Transcription Factor Trps1. NCI Thesaurus. Code C75524.

Zinc finger transcription factor Trps1 (1281 aa, 142 kDa) is encoded by the human TRPS1 gene. This protein is involved in the negative regulation of transcription. 